\title{
Transesophageal lung ultrasound: to boldly go...
}

\author{
A. Stéphane Lambert, MD • Robert Chen, MD
}

Received: 6 June 2016/Accepted: 13 July 2016/Published online: 29 July 2016

(C) Canadian Anesthesiologists' Society 2016

Since its introduction in the early 1980s, transesophageal echocardiography (TEE) has grown to become a standard of care in cardiac anesthesia and a widely used diagnostic tool in many non-cardiac anesthesia environments. In critical care, TEE and transthoracic echocardiography (TTE) combine to provide us with a better understanding of cardiac function and hemodynamics. Indeed, echocardiography is so ubiquitous in anesthesia practice that many think it should be a fundamental cognitive skill taught to all anesthesiology trainees during residency. ${ }^{1,2}$

Thanks to its access to multiple acoustic windows, surface ultrasound can evaluate many organ systems other than the heart, leading to the everyday use of "point of care ultrasound" (POCUS) in many perioperative diagnostic situations, as well as in the intensive care unit and the emergency department. With POCUS, we can examine the inferior vena cava (IVC), liver, spleen, kidneys, bladder and, of particular importance to anesthesiologists, the lungs and pleural spaces. In the latter setting, POCUS relies on artifacts generated at various air-tissue interfaces within the chest to make inferences about various lung conditions such as consolidation, edema, effusions, and pneumothorax..$^{3-5}$

Until now, the use of TEE has focused mainly on the heart, due to obvious limitations imposed by its position in the esophagus, but it can "see" other organs as well. The American Society of Echocardiography/Society of Cardiovascular Anesthesiologists comprehensive perioperative examination includes images of the IVC

A. S. Lambert, MD $(\bowtie) \cdot$ R. Chen, MD

Division of Cardiac Anesthesiology, University of Ottawa Heart Institute, H2410 - 40 Ruskin Street, Ottawa, ON K1Y 4W7, Canada

e-mail: slambert@ottawaheart.ca and hepatic veins as part of the assessment of right atrial pressure, and the ascending and descending aortas are routinely surveyed by TEE. ${ }^{6}$ Furthermore, the literature contains many reports of TEE imaging of the pleuras, kidneys, and even the spinal cord. ${ }^{7-9}$

In this issue of the Journal, Cavayas et al. present a detailed review of transesophageal lung ultrasound (TELU). ${ }^{10}$ The manuscript is divided into three parts. First, the authors summarize the known science surrounding lung ultrasound and the physics behind various imaging artifacts. They then describe how the various concepts of surface lung ultrasound can apply to TELU, being careful to acknowledge the lack of validation of many of these concepts. Where no scientific data exist, the authors substitute their expert opinion in a candid and very lucid way about what should or should not be extrapolated from surface lung ultrasound to TELU. In the last section of their manuscript, the authors suggest an integrated cardiopulmonary approach to TEE diagnosis, in a fashion similar to the POCUS approaches previously published. $^{11}$

Far from being on the "fringe", this manuscript formalizes examinations that many of us have been doing informally for years. Indeed, TEE-able physicians have often scanned and reported on lung findings, although neither in a protocolized fashion nor with any degree of quantification. As an example, poor venous return while on bypass will often prompt a TEE search of the pleural cavities for sequestered blood. In this review, the authors challenge us to perform many of the same examinations as before, but in a more systematic way and at a higher "evidence-based" level.

Transesophageal lung ultrasound obviously has many significant limitations, the most important being the lack of experimental validation. Most of the imaging concepts 
presented here were validated using surface ultrasound, and the reader is cautioned against unwarranted generalization, for several reasons. First, much of the original research on surface lung ultrasound was conducted using micro-convex probes that lacked many of the features commonly found on modern TEE probes. Since much of lung ultrasonography relies on the analysis of artifacts, using different types of probes with different physical characteristics can have a significant impact on the diagnostic value of the images. In addition, since many of the features on modern TEE probes (e.g., adjustable frequency, power, and focus, as well as harmonic imaging and post-processing of the received signal) are designed to eliminate those very artifacts that are needed for lung ultrasonography, one must be very careful extrapolating the existing data. ${ }^{5}$ Another important factor is the fact that the vantage point (i.e., acoustic window) for TELU is in the posterior mediastinum, in patients who are in the supine position and usually receiving mechanical ventilation. Many of the artifacts used for surface lung ultrasound (e.g., A-lines and B-lines) rely on recognized and validated relationships between various layers of tissues that the ultrasound beam encounters on its path. In supine patients, gravity leads to specific, recognized, and validated distributions of air and water. When the ultrasound beam approaches the lung from behind, some of these relationships could potentially lead to different artifacts and different diagnostic criteria. What is the diagnostic value of those recognized signs? Do we know with confidence that they apply equally to TELU? Once again, the lack of validation of lung imaging using TEE cannot be overstated.

Be that as it may, the authors did an impressive job of summarizing the existing knowledge about lung ultrasound and applying their vast experience and expertise to guide the reader through applications of TEE that are probably valid but not yet validated. For many readers, this review will open a window on the tremendous power of lung ultrasound. For others, it will be a reminder that TEE can image many structures other than the heart and that there remains much uncharted territory to be explored in the world of TEE.

In this brave new world, where ultrasound is increasingly viewed as the new stethoscope and where TEE and surface sonography are two aspects of the same powerful diagnostic tool for anesthesiologists, Cavayas et al. challenge us to look at the heart, not in isolation from other structures but in an integrated multi-organ approach that is likely to provide better diagnostic information for the benefit of our patients.

\section{Échographie transoesophagienne pulmonaire: le futur maintenant}

Depuis son introduction au début des années 1980, l'échographie transœsophagienne (ETO) est devenue un standard de pratique en anesthésie cardiaque, et un outil diagnostique fréquemment utilisé également en anesthésie non cardiaque. En réanimation, l'ETO et l'échocardiographie transthoracique (ETT) se complètent pour aider à mieux comprendre l'hémodynamie et la fonction cardiaque des patients. En fait, l'échocardiographie est si répandue que plusieurs considèrent qu'une connaissance de base en échographie est un élément fondamental du curriculum de résidence en anesthésie. ${ }^{1,2}$

Grâce à sa capacité d'accès à plusieurs fenêtres acoustiques, l'échographie de surface permet d'examiner plusieurs organes autres que le cœur, ce qui a donné lieu à l'usage courant de l'échocardiographie ciblée (en anglais « Point of Care Ultrasound» ou «POCUS»), en réanimation et à la salle d'urgence. Dans ce contexte, POCUS peut évaluer la veine cave inférieure, le foie, la rate, les reins, la vessie et surtout, du point de vue de l'anesthésiste, les poumons et plèvres. L'échographie pulmonaire se base sur l'interprétation d'artéfacts qui sont créés par les faisceaux d'ultrasons traversant les interfaces air/tissu, révélant ainsi l'état des poumons : œdème, consolidation, épanchement, pneumothorax. ${ }^{3-5}$

À cause des restrictions imposées par son emplacement dans l'œsophage, l'ETO s'est jusqu'à maintenant concentrée sur l'évaluation cardiaque, mais elle peut en fait aussi «voir»d'autres organes. En effet, l'examen d'ETO complet, tel que recommandé par l'American Society of Echocardiography/Society of Cardiovascular Anesthesiologists, inclut une étude de la veine cave inférieure et des veines hépatiques, pour estimer la pression dans l'oreillette droite, ainsi que l'aorte ascendante et descendante. ${ }^{6}$ En outre, la littérature comporte plusieurs comptes rendus d'ETO des plèvres, des reins, et même de la moelle épinière. ${ }^{7-9}$

Dans ce numéro du Journal, Cavayas et coll. nous présentent une revue détaillée de l'échographie transœsophagienne pulmonaire (ETOP). ${ }^{10}$ L'article est divisé en trois parties: d'abord, les auteurs résument les connaissances actuelles en ce qui a trait à l'échographie pulmonaire, ainsi que les principes physiques derrière les 
artéfacts dont dépend l'examen ultrasonographique des poumons. Dans un deuxième temps, ils nous expliquent la façon dont les divers concepts portant sur l'échographie pulmonaire s'appliquent à l'ETOP, en prenant soin de reconnaître que plusieurs de ces concepts n'ont jamais été validés scientifiquement pour l'ETO. Lorsqu'il n'existe pas de données scientifiques, les auteurs donnent leur opinion experte de façon à la fois candide et lucide quant à ce qui pourrait ou non être extrapolé de l'échographie de surface à l'ETOP. Enfin, les auteurs nous proposent une approche cardiopulmonaire intégrée de l'examen d'ETO, qui se rapproche de celles publiées pour l'examen de surface POCUS. $^{11}$

Loin d'être marginal, ce rapport «formalise » des techniques que plusieurs d'entre nous avons utilisées depuis des années. En effet, bien des anesthésistes ont regardé les poumons à l'ETO, sauf qu'il n'y avait ni protocole, ni évaluation quantitative (par exemple, qui d'entre nous n'a pas recherché un épanchement pleural pour expliquer une baisse de retour veineux sur circulation extracorporelle (CEC)?). Les auteurs nous mettent au défi de pratiquer les mêmes examens, mais de le faire de façon plus systématique.

L'ETOP est limitée par plusieurs facteurs, dont le plus important est le manque de validation empirique. En effet, la plupart des concepts discutés dans cet article ont été validés par échographie de surface, et nous mettons en garde le lecteur contre une généralisation hâtive, pour deux raisons : d'abord, les études initiales sur l'échographie pulmonaire ont été réalisées avec des sondes d'échographie micro-convexes, lesquelles ne possédaient aucune des caractéristiques retrouvées sur les sondes d'ETO modernes. Étant donné que l'échographie pulmonaire se base sur l'analyse d'artéfacts, l'utilisation d'un type de sonde différent risque de changer la valeur diagnostique des images obtenues. Ceci est d'autant plus vrai que plusieurs des caractéristiques des sondes modernes (par exemple, les possibilités d'ajustement de la fréquence, de la puissance et du foyer ainsi que l'imagerie harmonique et le post-traitement du signal reçu) ont été introduites dans le but de supprimer les artéfacts dont on a justement besoin pour évaluer les poumons par échographie. Il convient donc d'user de prudence lorsqu' on souhaite extrapoler les données existantes. ${ }^{5}$ Deuxièmement, le point de vue de l'ETOP (c.-à-d. la fenêtre acoustique) est dans le médiastin postérieur, chez des patients qui sont habituellement en position couchée, et sous ventilation mécanique. Plusieurs des artéfacts utilisés en échographie pulmonaire (par ex. lignes A et lignes B) dépendent d'une interaction connue et validée des faisceaux d'ultrasons avec les différentes couches de tissus pulmonaires traversées par ces faisceaux. En position couchée, la gravité produit une distribution de l'air et de l'eau dans les poumons qui est elle aussi reconnue et validée. Quand un faisceau d'ultrasons aborde le poumon de l'arrière, cela pourrait produire des artéfacts différents, et des critères diagnostiques différents aussi. Quelle est donc la valeur diagnostique de tous ces signes reconnus? Peut-on dire que ces signes diagnostiques s'appliquent également à l'ETOP? Encore une fois, il convient d'insister sur le manque de validation expérimentale de l'ETOP.

Ceci étant dit, les auteurs ont tout de même très bien résumé l'état des connaissances sur l'échographie pulmonaire, et y ont joint leur vaste expertise dans ce domaine, pour guider le lecteur à travers les diverses applications de l'ETOP qui sont probablement valides, mais qui n'ont jamais été validées. Cet article ouvre une fenêtre sur le potentiel diagnostique de l'échographie pulmonaire. Il nous rappelle aussi que l'ETO peut examiner d'autres organes que le cœur, et que plusieurs aspects du monde de l'ETO demeurent inexplorés.

Dans un monde où la sonde d'échographie est devenue le nouveau stéthoscope, et où l'ETO et l'échographie de surface sont deux applications du même outil diagnostique, Cavayas et coll. nous proposent d'inclure cœur et poumons dans une approche intégrée, ce qui produira sans doute plus d'informations diagnostiques pour le bien de nos patients.

Conflicts of interest None declared.

Editorial responsibility This submission was handled by Dr. Hilary P. Grocott, Editor-in-Chief, Canadian Journal of Anesthesia.

\section{Conflit d'intérêt Aucun.}

Responsabilité éditoriale Cet article a été traité par Dr Hilary P. Grocott, rédacteur en chef, Journal canadien d'anesthésie.

\section{References}

1. Mahmood F, Matyal R, Skubas $N$, et al. Perioperative ultrasound training in anesthesiology: a call to action. Anesth Analg 2016; 122: $1794-804$

2. Ramsingh D, Rinehart $J$, Kain $Z$, et al. Impact assessment of perioperative point-of-care ultrasound training on anesthesiology residents. Anesthesiology 2015; 123: 670-82.

3. Lichtenstein D, Meziere G, Biderman P, Gepner A, Barre O. The comet-tail artifact. An ultrasound sign of alveolar-interstitial syndrome. Am J Respir Crit Care Med 1997; 156: 1640-6.

4. Lichtenstein D, Meziere G, Biderman P, Gepner A. The, "lung point": an ultrasound sign specific to pneumothorax. Intensive Care Med 2000; 26: 1434-40.

5. Lichtenstein DA, Meziere GA. Relevance of lung ultrasound in the diagnosis of acute respiratory failure: the BLUE protocol. Chest 2008; 134: 117-25.

6. Hahn RT, Abraham T, Adams MS, et al. Guidelines for performing a comprehensive transesophageal echocardiographic examination: recommendations from the American Society of Echocardiography and the Society of Cardiovascular Anesthesiologists. J Am Soc Echocardiogr 2013; 26: 921-64. 
7. Goswami V, Kumar B, Puri GD, Singh H. Utility of transesophageal echocardiography in identifying spinal canal structures and epidural catheter position: a prospective observational study of intraoperative hemodynamics and postoperative analgesia. Can J Anesth 2016. DOI:10.1007/ s12630-016-0650-x.

8. Bandyopadhyay S, Kumar Das R, Paul A, Sundar Bhunia K, Roy $D$. A transesophageal echocardiography technique to locate the kidney and monitor renal perfusion. Anesth Analg 2013; 116 : 549-54.

9. Rehfeldt KH, Bruggink SM, Pulido JN. Transesophageal echocardiographic imaging of ultrasound lung rockets. Anesthesiology 2014; 121: 1335
10. Cavayas YA, Girard $M$, Desjardins $G$, Denault $A Y$. Transesophageal lung ultrasonography: a novel technique for investigating hypoxemia. Can J Anesth 2016; 63: this issue. DOI: 10.1007/s12630-016-0702-2.

11. Pelosi P, Corradi F. Ultrasonography in the intensive care unit: looking at the world through colored glasses. Anesthesiology 2012; 117: 696-8. 